\title{
Studies on medicinal and toxicological properties of Cajanus cajan, Ricinus communis and Thymus vulgaris leaf extracts
}

\author{
O. I. Oyewole ${ }^{1 \star}$, A. A. Owoseni ${ }^{2}$ and E. O. Faboro ${ }^{3}$ \\ ${ }^{1}$ Department of Biochemistry, Osun State University, Osogbo, Osun State, Nigeria. \\ ${ }^{2}$ Department of Biological Sciences, Bowen University, Iwo, Osun State, Nigeria. \\ ${ }^{3}$ Department of Chemistry, Bowen University, Iwo, Osun State, Nigeria.
}

Accepted 6 August, 2010

\begin{abstract}
Methanolic extracts of the leaves of Cajanus cajan (pigeon pea), Ricinus communis (castor bean) and Thymus vulgaris (thyme) were investigated for their medicinal, antimicrobial and toxicological properties. Phytochemical screening of the leaves revealed the presence of tannins, phlobatannins, flavonoids, steroids, terpenoids, saponins and cardiac glycosides which are the most important bioactive constituents of medicinal plants. Antimicrobial testing against eight pathogenic bacteria showed that all the extracts possess antimicrobial properties with Thymus vulgaris being the most effective as it inhibited seven out of the eight bacteria tested. Rats were given daily oral administration of methanolic extracts of the leaves at two different concentrations $(100 \mathrm{mg}$ and $200 \mathrm{mg} / \mathrm{kg}$ body weight) for a period of 14 days. Analysis of kidney and liver function parameters in the serum and tissues of the rats show no significant difference $(P<0.05)$ between treated and untreated rats. Measurement of organ: body weight ratio did not show any indication of kidney or liver enlargement. These results showed that the extracts are not toxic and also possess medicinal components which are inhibitory to bacteria.
\end{abstract}

Key words: Cajanus cajan, Ricinus communis, Thymus vulgaris, antimicrobial, toxicity.

\section{INTRODUCTION}

The incidence of bacterial infection in man is on the increase worldwide. Many antibiotic drugs currently in use are either too expensive or posses undesirable side effects while some are no more effective due to bacterial resistance (Alper, 1998). All these have led to increase in advocacy for the use of natural products in the prevention and cure of bacterial infections. A major contribution of medicinal plants to both traditional and modern healthcare systems is their limitless possession of a large number of bioactive components that produce definite physiological action in the body (Principle, 1989). The accumulation of these bioactive compounds in large proportions in plants has attracted the attention of the

\footnotetext{
*Corresponding author. E-mail: ioluoye@yahoo.com. Tel: +2348066808560 .
}

academic community over the last 5 decades which led to the identification of native medicinal plants in indigenous pharmacopeias (Adebolu and Oladimeji, 2005).

Cajanus cajan (pigeon pea), Ricinus communis (castor bean) and Thymus vulgaris (thyme) are medicinal plants which grow in the humid tropical secondary forests of Africa (Oliver-Bever, 1986). These plants are among several natural products used by traditional healers in Western Nigeria to treat a number of bacterial infections (Sofowora, 1993). Decoctions of the leaves were believed to have chemical components which are active against pathogenic microorganism. More people have continued to use these herbs for the treatment of different pathogenic infection in the absence of adequate toxicity data and proper understanding of their medicinal properties. Traditional medicine practitioners believe that these herbs are non-toxic even though there is no 
scientific backing to support this claim. We intend to investigate and provide adequate data in this study on the medicinal constituents, antimicrobial properties and toxicity of the herbs to determine their safety of otherwise.

\section{MATERIALS AND METHODS}

\section{Preparation of leaf extracts}

C. cajan, R. communis and T. vulgaris were obtained from Shao area, Kwara State Nigeria and properly identified at the Department of Biological Sciences (Botany Unit), Bowen University Iwo, Nigeria. The leaves were dried and pulverized into powdered form. Methanolic extracts of the leaves were prepared by taking $150 \mathrm{~g}$ dried sample and extracted with $900 \mathrm{ml}$ of $80 \%$ methanol for $24 \mathrm{~h}$. The mixture was filtered using Whatman filter paper $(125 \mathrm{~mm})$ and evaporated to dryness using a rotatory evaporator to give a darkbrown crude extract which was stored in the refrigerator in reagent bottles.

\section{Phytochemical screening}

Phytochemical screening of the extracts were carried out for the presence of tannins, phlobatannins, flavonoids, steroids, terpenoids, saponins and cardiac glycosides using standard procedures as described by Sofowora (1993) and Trease and Evans (1989) and Harborne (1973).

\section{Antimicrobial investigation}

The extracts were tested against eight major bacterial namely Staphylococcus aureus, Escherichia coli, Salmonella, Bacillus subtilis, Citrobacter, Proteus vulgaris, Pseudomonas and Micrococcus sp using the broth dilution assay procedure (Nostro et al., 2000). The minimum inhibitory concentration (MIC) of the extracts was also determined following standard methods as described by Burt and Reinders (2003).

\section{Handling of experimental animals}

Sixty (60) Fischer strain albino rats (Rattus novergicus) with average weight $150 \mathrm{~g}$ were used for the study. They were obtained from the Animal House of the Department of Biochemistry, University of Ilorin, Nigeria. The rats were kept in well-ventilated house conditions (temperature: $28-31^{\circ} \mathrm{C}$; photoperiod: $12 \mathrm{~h}$ natural light and $12 \mathrm{~h}$ dark; humidity: $50-55 \%$ ) and given normal rat feed and water ad libitum. They were randomly divided into four experimental groups. Group A served as the control and were administered with distilled water. Group B received leaf extract of $C$. cajan, Group C: R. communis and Group D: T. vulgaris. Each groups were subdivided into two depending on the dose of extract administered (100 or $200 \mathrm{mg} / \mathrm{kg}$ body weight). The extracts were administered daily for a period of 14 days.

\section{Preparation of serum and tissue homogenate}

The rats were sacrificed at the end of the experimental period and their venous blood collected into clean sample bottles. This was allowed to clot and then centrifuged at $3000 \mathrm{rpm}$ for $5 \mathrm{~min}$ after which the serum was separated and stored frozen until needed for analysis. After bleeding, the animals were quickly dissected and their tissues (liver and kidneys) removed and homogenized in ice cold $0.25 \mathrm{M}$ sucrose solution (1:5 w/v). The homogenate was kept frozen overnight to ensure maximum release of the enzymes.

\section{Measurement of toxicological parameters}

Kidney and liver function tests (measured with Randox test kits) were employed as tool for investigating toxicity of the herbs. The method of Wright et al. (1972) was used for the essay of alkaline phosphatase (ALP). Aspartate aminotransferase (AST) and Alanine aminotransferase (ALT) were assayed as described by Reitman and Frankel (1957). Serum urea concentration was determined by the method of Veniamin and Vakirtzi (1970). Serum creatinine was determined using the Jaffe reaction (Tietz et al., 1994) while serum sodium and potassium ions were determined by flame photometry using the Jenway Clinical PFP7 Flame Photometer.

\section{Chemicals/reagent kits and nutrient agar}

All chemicals/reagent kits and Agar media used for the study were of analytical grade (ANALAR). They were obtained from British Drug House, Poole England.

\section{Statistical analysis}

Data obtained were analyzed using Duncan multiple range test following one way analysis variance (ANOVA). Differences at $\mathrm{P}<0.05$ were considered significant.

\section{RESULTS}

Results obtained for phytochemical screening of the leaf extracts is shown in Table 1. C. cajan contained all the seven tested phytochemicals except terpenoids, $R$. communis contained all except steroids and saponins while $T$. vulgaris contained all except steroids. Table 2 and Plate 1 show the zone of inhibition of microbial agents by leaf extracts of the three herbs. C. cajan was the least active of all the three tested as it was only effective on $P$. Aeruginosa. T. vulgaris was effective against all the microorganisms except $E$. coli with pseudomonas having the widest zone of inhibition (26 $\mathrm{mm})$. $R$. communis was effective against only four organisms.

The results of MIC carried out only on $T$. vulgaris extract being the most effective of the three herbs is shown in Figure 1. The MIC for $P$. vulgaris was $10 \mathrm{mg} / \mathrm{ml}$ while Citrobacter and $B$. subtilis were inhibited at 5 $\mathrm{mg} / \mathrm{ml}$. $2.5 \mathrm{mg} / \mathrm{ml}$ was the minimum concentration that inhibited P. aeruginosa, Micrococcus sp., Salmonella and S. aureus.

Results obtained for concentrations of some serum metabolites in the rats is shown in Table 3 while that of the enzyme levels in the kidney and liver is shown in Table 4. There were no significant difference $(P<0.05)$ in the serum and tissues levels of ALP, ALT and AST in the test groups compared with the control. Serum 
Table 1. Qualitative analysis of phytochemicals present in the leaf extracts.

\begin{tabular}{lccc}
\hline Compound & C. cajan & R. communis & T. vulgaris \\
\hline Tannins & + & + & + \\
Phlobatannins & + & + & + \\
Flavonoids & + & + & + \\
Steroids & + & - & - \\
Terpenoids & - & + & + \\
Saponins & + & - & + \\
Cardiac glycosides & + & + & + \\
\hline
\end{tabular}

+ Positive, - Negative.

concentrations of urea, creatinine, $\mathrm{Na}+$ and $\mathrm{K}+$ in the test groups and that of the control also indicated no significant difference at the end of the experimental period. Table 5 show the result obtained for measurement of organ: body ratio of the rats administered with the leaf extracts. There was no significant difference in the kidney: body weight ratio and liver: body weight ratio in the test groups administered with $200 \mathrm{mg} / \mathrm{kg}$ body weight compared with the control.

\section{DISCUSSION}

\section{Medicinal properties}

All the three leaf extracts contain at least five out of the seven important bioactive constituents of medicinal plants tested which are tannins, phlobatannins, flavonoids, steroids, terpenoids, saponins and cardiac glycosides. These components account for their effectiveness against at least one microbial agent tested. Plants have an almost limitless ability to synthesize aromatic substances, most of which are phenols or their oxygensubstituted derivatives (Olukoya et al., 1992). These substances serve as plant defense mechanisms against predation by microorganisms, insects and herbivores (Cowan, 1999). Terpenoids contain essential oil derivatives which are inhibitory to bacterial (Aureli et al., 1992). Tannins complex with proteins in bacterial through nonspecific forces such as hydrogen bonding and hydrophobic effects and render them ineffective. Many human physiological activities, such as stimulation of phagocytic cells, host-mediated tumor activity, and a wide range of anti-infective actions, have been assigned to tannins (Butler, 1988).

The mechanisms thought to be responsible for antimicrobial activity of steroids include enzymes inhibition by the oxidized compounds, possibly through reaction with sulfhydryl groups or through more nonspecific interactions with the proteins (Brantner and Grein, 1994). The mechanism of action of saponins is not fully understood but is speculated to involve membrane disruption by the lipophilic compounds. They also
Table 2. Effects of the leaf extracts on test bacteria.

\begin{tabular}{clcccc}
\hline S/N & Test bacteria & Gram & A (mm) & B (mm) & C (mm) \\
\hline 1 & Citrobacter sp. & - & - & - & 12 \\
2 & S. typhi & - & - & 9.0 & 19 \\
3 & E. coli & - & - & - & - \\
4 & P. vulgaris & - & - & - & 10 \\
5 & P. aeruginosa & - & 13 & 9.5 & 26 \\
6 & Micrococcus sp. & + & - & 6.0 & 18 \\
7 & B. subtilis & + & - & 7.0 & 12 \\
8 & S. aureus & + & - & - & 19 \\
\hline
\end{tabular}

$\mathrm{A}=C$. cajan leaf extract, $\mathrm{B}=R$. communis leaf extract, $\mathrm{C}=T$. vulgaris leaf extract, Test concentration $=40 \mathrm{mg} / \mathrm{mL}$.

inactivate microbial adhesions. Flavonoids are known to complex irreversibly with amino acids of bacterial often leading to inactivation of the protein and loss of function. Flavonoids may also render substrates unavailable to the microorganism (Akpata and Akinrimisi, 1977). The activity of the plant extracts against both Gram positive and Gram negative bacteria is an indication of the presence of broad spectrum antibiotic compounds or metabolic toxins in the plant (Parekh and Chanda, 2007). Results obtained showed that the extracts were more active against Gram-positive bacteria than Gram-negative bacteria.

This could be ascribed to the morphological differences between these microorganisms (Nostro et al., 2000). Gram negative bacteria have an outer phospholipids membrane carrying the structural lipopolysaccharide components, which makes the cell wall partially impermeable. Gram-positive bacteria however have only an outer peptidoglycan layer which is not an effective permeability barrier and are thus more susceptible (Nikaido and Vaara, 1985).

\section{Toxicological properties}

There were no significant difference $(P<0.05)$ in the serum and tissues levels of ALP, ALT and AST in the test groups compared with the control as shown in Tables 3 and 4 . These results indicated that the extract did not bring pronounced cellular damage in the liver and kidney of the rats during the experimental period. Enzyme activities in the serum and tissues are often used as 'marker' to ascertain early toxic effects of administered foreign compounds to experimental animals (Coodley, 1970). ALP is a membrane bound enzyme while ALT and AST are cytosolic enzymes. These enzymes are highly concentrated in the liver and kidney and are only found in serum in significant quantities when the cell membrane becomes leaky and even completely ruptured (Cotran et al., 1989). A rise in serum level or decrease in tissue level of these intracellular enzymes is an index of damage to liver and kidney cells (Moss and Rosalki, 1996). 


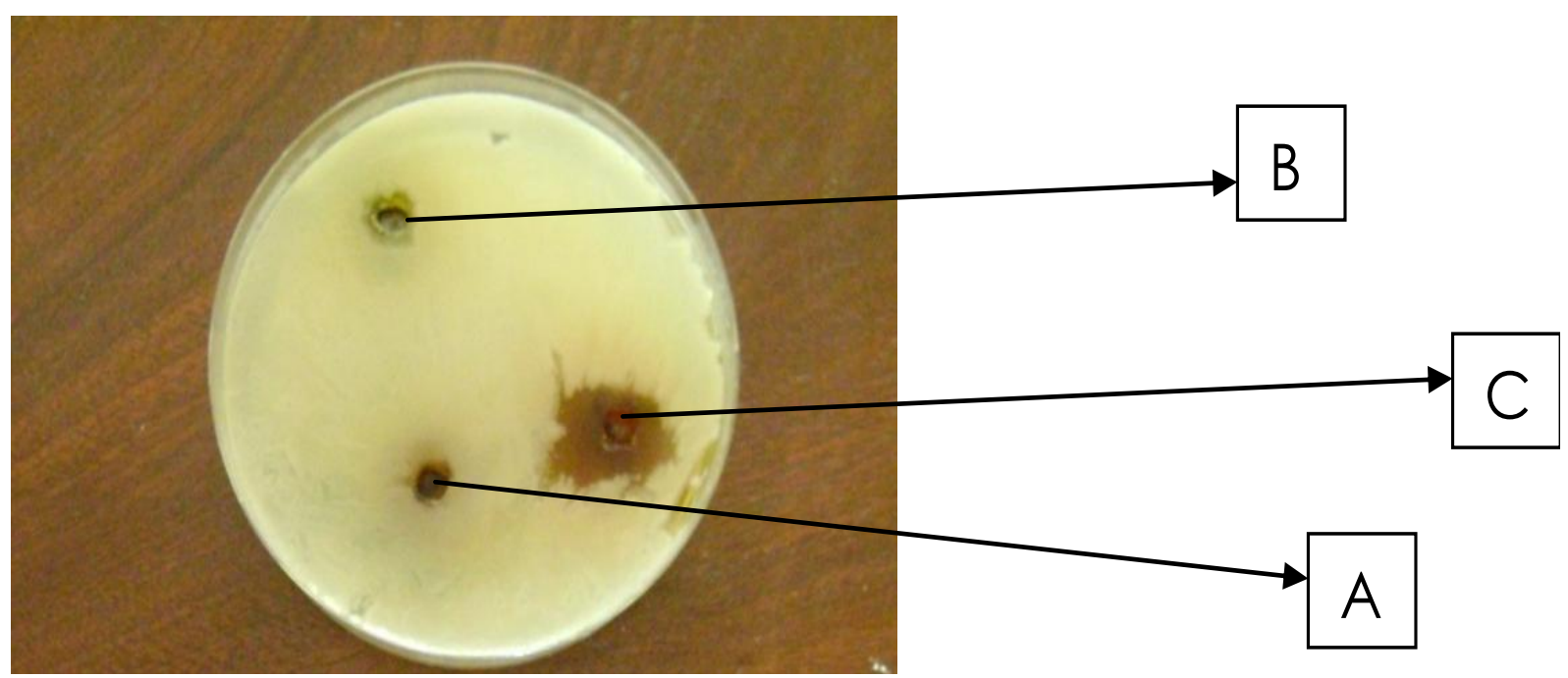

Plate 1. Zones of inhibition of the different extracts on P.aeruginosa. $\mathrm{A}=C$. cajan extract, $\mathrm{B}=R$. communis extract, $\mathrm{C}=T$. vulgaris extract.

Table 3. Some kidney and liver function parameters in the serum of rats administered with the leaf extracts.

\begin{tabular}{|c|c|c|c|c|c|c|c|}
\hline \multirow[b]{2}{*}{ Parameter } & \multirow[b]{2}{*}{ Control } & \multicolumn{2}{|c|}{ C. cajan } & \multicolumn{2}{|c|}{ R. communis } & \multicolumn{2}{|c|}{ T. vulgaris } \\
\hline & & $\begin{array}{c}100 \mathrm{mg} / \mathrm{kg} \\
\mathrm{bw}\end{array}$ & $\begin{array}{c}200 \mathrm{mg} / \\
\mathrm{kg} \mathrm{bw}\end{array}$ & $\begin{array}{c}100 \mathrm{mg} / \\
\mathrm{kg} \mathrm{bw}\end{array}$ & $\begin{array}{c}200 \mathrm{mg} / \\
\mathrm{kg} \mathrm{bw}\end{array}$ & $\begin{array}{c}100 \mathrm{mg} / \\
\mathrm{kg} \mathrm{bw}\end{array}$ & $\begin{array}{c}200 \mathrm{mg} / \\
\mathrm{kg} \mathrm{bw}\end{array}$ \\
\hline ALP (IU/L) & $53.4 \pm 5.2$ & $55.1 \pm 4.7$ & $55.5 \pm 3.2$ & $54.6 \pm 3.9$ & $54.1 \pm 3.3$ & $52.1 \pm 3.9$ & $53.1 \pm 4.6$ \\
\hline ALT (IU/L & $32.3 \pm 5.1$ & $36.1 \pm 4.2$ & $35.4 \pm 4.3$ & $34.9 \pm 4.6$ & $33.9 \pm 4.7$ & $33.8 \pm 3.7$ & $33.3 \pm 4.9$ \\
\hline AST (IU/L) & $71.3 \pm 4.8$ & $68.4 \pm 2.3$ & $70.0 \pm 3.6$ & $70.7 \pm 3.8$ & $69.6 \pm 4.8$ & $72.2 \pm 3.8$ & $70.8 \pm 5.1$ \\
\hline $\mathrm{Na}+(\mathrm{mmol} / \mathrm{L})$ & $121.3 \pm 15.9$ & $119.8 \pm 13.6$ & $120.2 \pm 14.2$ & $119.8 \pm 16.1$ & $120.5 \pm 15.5$ & $122.3 \pm 10.7$ & $120.2 \pm 16.6$ \\
\hline $\mathrm{K}+(\mathrm{mmol} / \mathrm{L})$ & $4.33 \pm 0.38$ & $4.68 \pm 0.41$ & $4.57 \pm 0.26$ & $4.48 \pm 0.41$ & $4.50 \pm 0.22$ & $4.26 \pm 0.27$ & $4.29 \pm 0.22$ \\
\hline Urea (mmol/L) & $5.12 \pm 0.58$ & $5.44 \pm 0.46$ & $5.33 \pm 0.47$ & $4.98 \pm 0.55$ & $5.00 \pm 0.35$ & $4.87 \pm 0.45$ & $4.94 \pm 0.38$ \\
\hline Creatinine $(\mathrm{mmol} / \mathrm{L})$ & $36.6 \pm 2.6$ & $38.3 \pm 2.1$ & $37.4 \pm 2.3$ & $36.9 \pm 2.0$ & $37.0 \pm 2.6$ & $37.2 \pm 2.4$ & $37.6 \pm 2.1$ \\
\hline
\end{tabular}

Values are Mean $\pm S D(I U / L), n=8$, all values along each row are not significantly different at $P<0.05$.

Table 4. Enzyme activities in the liver and kidney of rats administered with the leaf extracts.

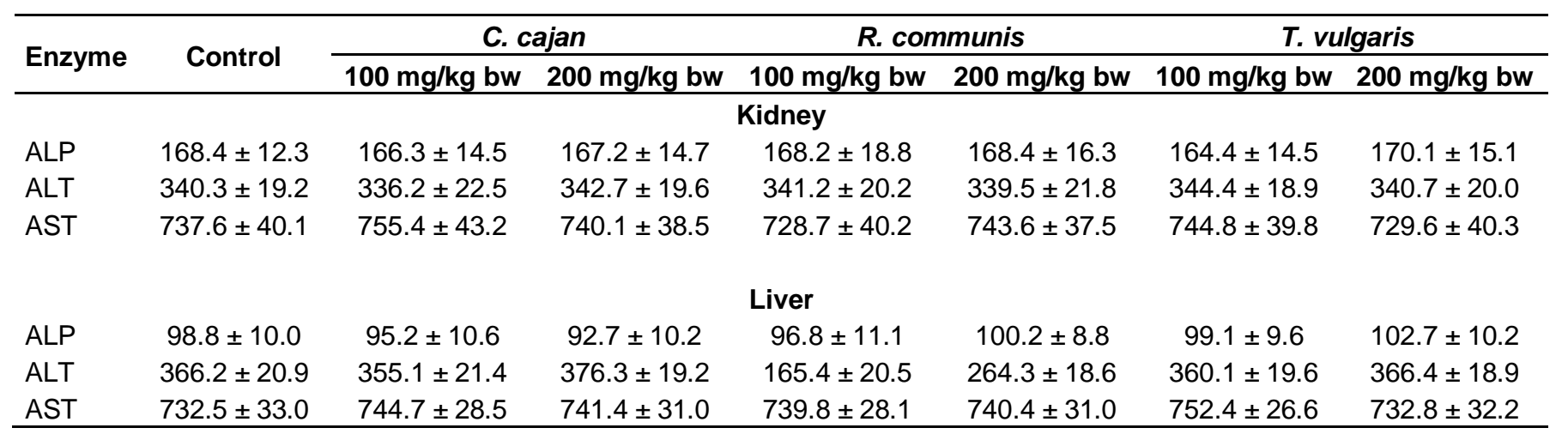

Values are Mean $\pm S D(I U / L), n=8$, all values along each row are not significantly different at $P<0.05$.

Results obtained for serum concentrations of urea and creatinine in the test groups were not significantly different from the control (Table 3) which showed that the extracts did not cause derangement in cellular activities 
Table 5. Organ: body weight ratio of rats administered with the leaf extracts.

\begin{tabular}{lcccc}
\hline Tissue & Control & C. cajan 200 $\mathbf{~ m g / k g ~ b w ~}$ & R. communis 200 $\mathbf{~ m g / k g ~ b w ~}$ & T. vulgaris 200 $\mathbf{~ m g / k g ~ b w ~}$ \\
\hline Kidney & $0.022 \pm 0.001$ & $0.024 \pm 0.002$ & $0.025 \pm 0.002$ & $0.023 \pm 0.001$ \\
Liver & $0.039 \pm 0.002$ & $0.038 \pm 0.003$ & $0.036 \pm 0.004$ & $0.034 \pm 0.002$ \\
\hline
\end{tabular}

Values are Mean $\pm S D(I U / L), n=8$, all values along each row are not significantly different at $P<0.05$.

in the rat's tissues. Urea and creatinine are waste products which are passed into the blood stream to be removed by the kidney. Alteration in the level of these waste products in the blood (serum) is an indication of renal function impairment (Cameron and Greger, 1998). Serum concentrations of $\mathrm{Na}+$ and $\mathrm{K}+$ in the test groups and that of the control as shown in Table 3 indicated no significant difference between the four groups. The fact that these electrolytes were not elevated in the serum showed that the osmotic regulatory function of the kidney was not affected upon administration of the extract. There was no significant difference in organ: body weight ratio in the test groups administered with $2.0 \mathrm{~g} / \mathrm{kg}$ body weight compared with the control as seen in Table 5. This result indicated that the extract did not cause kidney or liver enlargement in the rats.

\section{Conclusion}

Results obtained in this study indicated that $C$. cajan, $R$. communis and $T$. vulgaris all contain bioactive medicinal principles which account for their inhibitory actions against the bacterial tested. $T$. vulgaris appear to be the most active as it inhibited seven out of the eight bacteria. Oral administration of the leaf extracts of the herbs at the concentration tested is safe as they did not cause significant alteration in cellular activities of the experimental animals.

\section{ACKNOWLEDGEMENT}

This work was financed through the Research Grant offered by Bowen University Iwo Nigeria. We appreciate the Committee of Provost, Deans and Directors (CPDD) and the University Management for making fund available to carry out the research work.

\section{REFERENCES}

Adebolu TT, Oladimeji SA (2005). Antimicrobial activity of leaf extracts of Ocimum gratissmum on selected diarrhea causing bacteria in South-Western Nigeria. Afr. J. Biotechnol., 4(7): 682-684.

Akpata ES, Akinrimisi EO (1977). Antibacterial activity of extracts from some African chewing sticks. Oral Surg. Oral Med. Oral. Pathol., 44: 717-722.
Alper J (1998). Effort to combat microbial resistance lags. Am. Soc. Microbiol. News., 64: 440-441.

Aureli PA, Costantini S, Zolea T (1992). Antimicrobial activity of some plant essential oils against Listeria monocytogenes. J. Food. Prot., 55: 344-348.

Brantner A, Grein E (1994). Antibacterial activity of plant extracts used externally in traditional medicine. J. Ethnopharmacol., 44: 35-40.

Burt SA, Reinders RD (2003). Antibacterial activity of selected plant essential against Escherichia coli. Lett. Appl. Microbiol., 36: 162-167.

Butler LG (1988). Effect of condensed tannins on animal nutrition. In: Chemistry and significance of condensed tannins. (Hemingway RW and Carchesy JJ Eds.) Plenum Press New York. p. 553.

Cameron JS, Greger R (1998). Renal function and testing of function. (Davison AM, Cameron JS, Grunfeld JP, Kerr DNS., Rits E, Winearl GC eds.) Oxford Textbook Clin. Nephrol., pp. 36-39.

Coodley E (1970). Diagnostic enzymology. Lea and Febiger PennysIvania, pp. 48-50.

Cotran R, Kumar V, Robins S (1989). Robins pathological basis of disease. $4^{\text {th }}$ edition. WB Saunders Co. Harcourt.pp 34-37.

Cowan MM (1999) Plant products as antimicrobial agents. Clinical. Microbiol. Rev., 12(4): 564-582.

Harborne JB (1973). Phytochemical methods. London Chapman and Hall Ltd. Pp. 49- 188. Moss DW, Rosalki SB (1996). Enzyme tests in diagnosis. Edward Arnold. London. pp. 68-77.

Nikaido H, Vaara M (1985). Molecular basis of bacterial outer membrane permeability. Microbiol. Rev., 1: 1-32.

Nostro A, Germano MP, D'Angelo V, Marino A, Cannatelli MA (2000). Extraction methods and bioautography for evaluation of medicinal plant antimicrobial activity. Lett. Appl. Microbiol., 30: 379-384.

Oliver-Bever B (1986). Medicinal plants in Tropical West Africa, $1^{\text {st }}$ ed. Cambridge University Press. pp. 87-101.

Olukoya DK, Idiaka N, Odugbemi T (1992). Anti-Microbial Activity of some Medicinal Plants from Nigeria. J. Ethnopharmacol., 39: 69-72.

Parekh J, Chanda S (2007). In vitro antimicrobial activity of Trapa natans Linn. Fruit extracted in different solvents. Afr. J. Biotechnol., 6(6): 766-770.

Principle P (1989). In: Economic and Medicinal Research. (Wagner H, Hikino, $H$. and Farnsworth, N.R. Eds.) Acad. Press, London., 3: 1-17.

Reitman S, Frankel S (1957). A colorimetric method for the determination of serum glutamic oxaloacetate aminotransferase. Am. J. Clin. Pathol., 28: 56-63.

Sofowora A (1993). Medicinal plants and traditional medicine in Africa. Spectrum BooksLtd, Ibadan, Nigeria. p. 289.

Tietz NW, Pruden EL, Siggaard-Anderson O (1994). In: Tietz textbook of Clinical Chemistry (Burtis CA, Ashwell ER eds.) WB Saunder Co. London. pp. 1354-1374.

Trease GE, Evans WC (1989). Pharmacognosy. $11^{\text {th }}$ Edn. Brailliar Tiridel Can. Macmillan Publishers. pp. 42-55.

Veniamin MP, Vakirtzi-Lemonia C (1970). Chemical bases of the carbamidodiacetyl micro method for estimation of urea, citruline and carbamyl derivatives. Clin. Chem., 16: 3-6.

Wright PJ, Plimmer DT, Leathwood PT (1972). Enzyme in rat urine. Alkaline Phosphatase. Enzymol., 42: 317-327. 